2008-01-01

\title{
A Microstrip Printed Dipole Solar Antenna Using Polycrystalline Silicon Solar Cells
}

\author{
S. Shynu \\ Technological University Dublin \\ Maria Roo Ons \\ Technological University Dublin \\ Giuseppe Ruvio \\ Technological University Dublin
}

See next page for additional authors

Follow this and additional works at: https://arrow.tudublin.ie/engschececon

Part of the Electrical and Computer Engineering Commons

\section{Recommended Citation}

Shynu, S. et al. (2008) A microstrip printed dipole solar antenna using polycrystalline silicon solar cells. AP-S 2008: IEEE Antennas and Propagation Society International Symposium,San Diego, California, 5-11 July, 2008, doi:10.1109/APS.2008.4619048

This Conference Paper is brought to you for free and open access by the School of Electrical and Electronic Engineering at ARROW@TU Dublin. It has been accepted for inclusion in Conference papers by an authorized administrator of ARROW@TU Dublin. For more information, please contact arrow.admin@tudublin.ie, aisling.coyne@tudublin.ie,gerard.connolly@tudublin.ie.

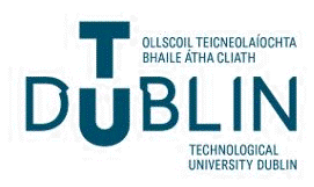




\section{Authors}

S. Shynu, Maria Roo Ons, Giuseppe Ruvio, Max Ammann, Sarah McCormack, and Brian Norton 


\title{
A Microstrip Printed Dipole Solar Antenna using Polycrystalline Silicon Solar Cells ${ }^{i}$
}

\author{
Shynu S.V*(1), Maria J. Roos Ons ${ }^{(1)}$, Giuseppe Ruvio ${ }^{(1)}$, Max J. Ammann ${ }^{(1)}$, \\ Sarah McCormack ${ }^{(2)}$ and Brian Norton ${ }^{(2)}$ \\ (1) School of Electronic and Communications Engineering, Dublin Institute of \\ Technology, Dublin, Ireland \\ (2) Dublin Energy Lab, Focas Institute, Dublin, Ireland \\ E-mail: sshynu@dit.ie
}

\section{Introduction}

Autonomous communication systems integrated with photovoltaic technology for low-cost and stand-alone applications receive much interest. The photovoltaic systems for power generation when combined with communications systems can provide compact and reliable autonomous communication systems for many applications. These devices often involve the use of separate solar cells and antennas, which necessitate a compromise in the utilization of the limited surface available. Many researchers explored the possibility of integrating microstrip antennas with photovoltaic solar cells for mobile and satellite communication applications [1-2]. Recently, integration of high efficiency polycrystalline silicon solar cells and microstrip patch antennas has been proposed for autonomous communication systems [3]. But in most of these reported solar antenna designs, the radiating element above the solar cell obstructs the incidence of light and thereby reduces the solar cell efficiency. Therefore a reduced size radiating element is always desirable for the integration. Microstrip printed dipole antennas are thus suitable candidates for the design of solar antennas with polycrystalline silicon solar cells. Here we propose a novel method of solar antenna design using a printed dipole integrated with a new type of balun attached to the solar cell.

\section{Solar Antenna Design}

The geometry of the proposed printed dipole solar antenna along with the microstrip balun is shown in Figure 1(a). To achieve total integration of the solar cell and the antenna, high efficiency polycrystalline silicon solar cells of dimension $15.6 \times 15.6 \times 0.026 \mathrm{~cm}$ developed by Solland were used as the reflector for the printed dipole antenna. The solar cell act as RF ground for the microstrip feed system and the balun is attached directly to the Ag-bus bars. The solar cell consists of an aluminium back contact layer of thickness $35.71 \mu \mathrm{m}$ and silicon $\mathrm{n}^{+}-\mathrm{p}-\mathrm{p}^{+}$layer with a thickness of $210.23 \mu \mathrm{m}$. The silver bus bars for DC collection have a thickness of $17.62 \mu \mathrm{m}$ giving an overall solar cell thickness of $0.026 \mathrm{~cm}$. The radiating element consists of a half wave length dipole printed on an FR4 substrate of thickness $\mathrm{h}=1.57 \mathrm{~mm}$ and $\epsilon_{\mathrm{r}}=4.3$. The stripline fed arm of

${ }^{\mathrm{i}}$ This work was supported by Science Foundation Ireland 
the printed dipole is shorted to the solar cell silver bus bars as shown in Figure 1(b). The other arm of the dipole is grounded directly to the silver grid of the solar cell through the stripline ground plane. A $50 \Omega$ microstrip line with solar cell as $\mathrm{RF}$ ground plane connects the dipole with the SMA. The dipole feed gap, $g$ and the offset distance $g_{x}$ for the printed balun are carefully adjusted to achieve better dipole antenna performance [4]. A detailed diagram of the printed dipole and the balun is shown in Figure 1(b).

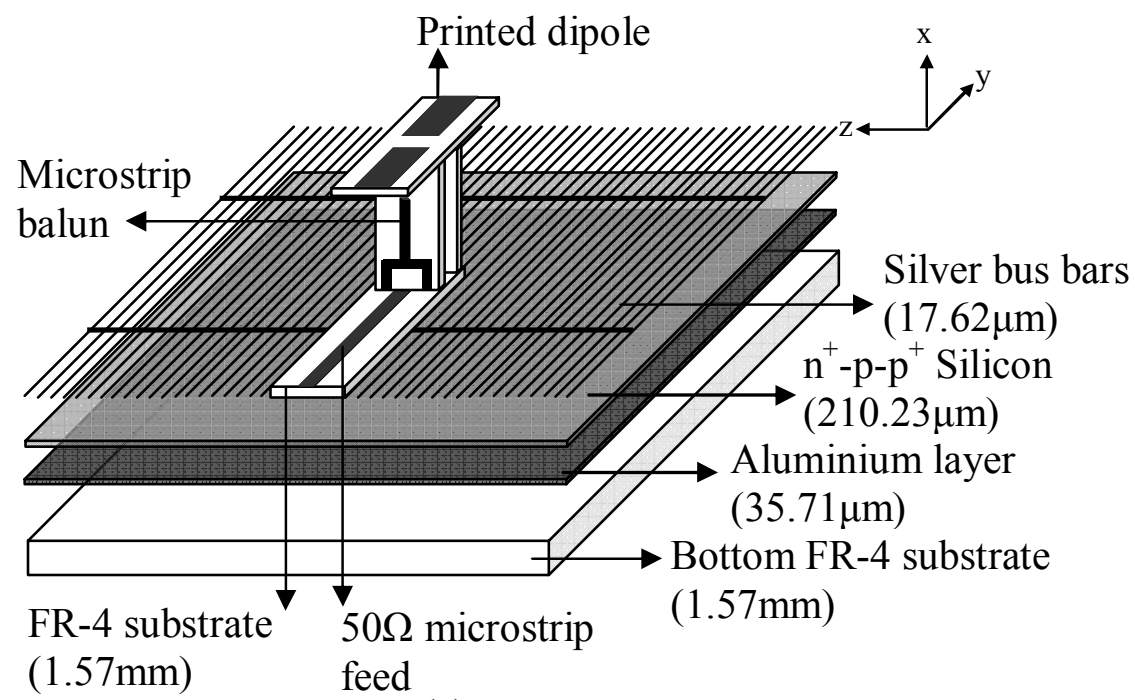

(a)

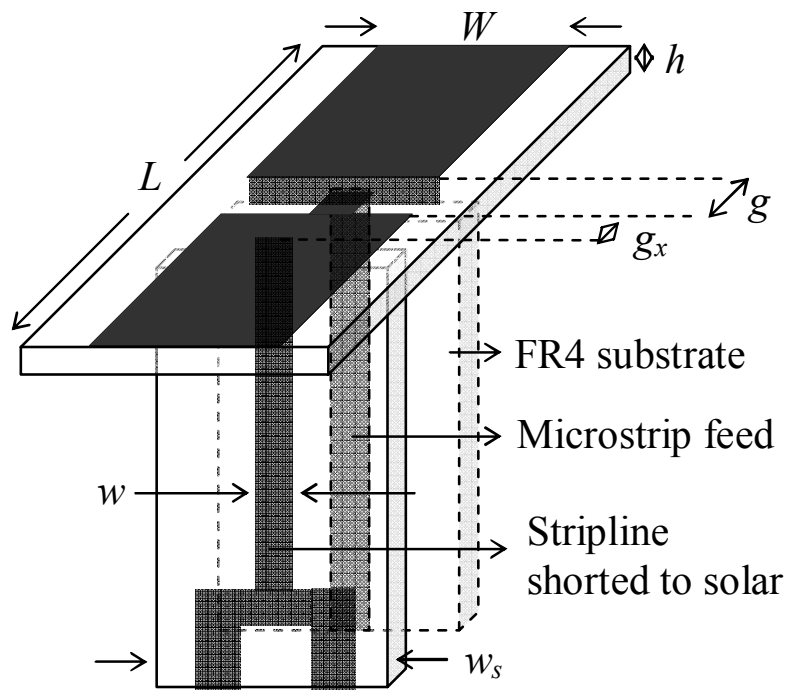

(b)

Figure 1. (a) Exploded layout of the proposed printed dipole solar antenna. (b) Geometry of the printed dipole and the balun.

For the proposed antenna applications, the design parameters chosen are, $L=$ $47 \mathrm{~mm}, W=5 \mathrm{~mm}, g=3 \mathrm{~mm}, g_{x}=2.5 \mathrm{~mm}, w_{s}=10 \mathrm{~mm}, \epsilon_{r}=4.3$, $\tan \delta=0.015$ and substrate height $h=1.57 \mathrm{~mm}$. CST Microwave Studio is used for the full wave optimization of the proposed solar antenna. Since the solar cell is acting both as 
$\mathrm{RF}$ ground for microstrip feed and as reflector for the dipole, the orientation of the $\mathrm{Ag}$ bus bars can affect the overall solar antenna performance. The desired orientation of the silver bus bars is along the y-axis, along the direction of the microstrip feed. Therefore, two prototypes were studied with the Ag-bus bars orienting along y-axis (Ag-parallel) and along z-axis (Ag-perpendicular) in order to compare the difference in the solar antenna performance.

\section{Results and Discussion}

The simulated $\mathrm{S}_{11}$ for the proposed solar antenna is given in Figure.2. A comparison is made with the printed dipole with an ideal PEC reflector. An impedance bandwidth of $15.8 \%$ is achieved with the Ag-parallel design. A comparison of the simulated antenna parameters are shown in Table I. Higher reflection of the surface currents occurs in the $\mathrm{Ag}$ grid, when it is oriented 'perpendicular' (z-direction) to the direction of the surface current flow (towards y-axis) in the Ag-grids. While, the ground currents in the Ag-grids for Ag-parallel orientation experience negligible reflection along y-direction and thus form a near ideal RF ground for the microstrip feed and better reflector for the dipole. The Ag-parallel solar antenna design gives a higher gain of $8.75 \mathrm{dBi}$.

Good undistorted radiation patterns are obtained for the solar antenna (Figure 3). The patterns remain essentially the same even after the ideal PEC reflector is replaced with the solar cell. More measured results and analysis will be presented at the symposium.

\section{Conclusion}

A novel printed dipole solar antenna design with an integrated balun is proposed for the first time with high efficiency polycrystalline silicon solar cells. The optimum orientation of the silver DC bus bars of the solar cell is determined in order to achieve best antenna performance. Good solar antenna performance similar to that of ordinary printed dipoles with PEC reflectors is achieved.

\section{References}

[1] N. Henze, M. Weitz, P. Hofmann, C. Bendel, J. Kirchoff and H. Fruchting, "Investigations on Planar Antennas with Photovoltaic Solar Cells for Mobile Communications", IEEE International Symposium on Personal, Indoor and Mobile Radio Communications, (PIMRC) vol-1, page- 622- 626, 2004.

[2] S. Vaccaro, J. R. Mosig and P. Maagt, "Two Advanced Solar Antenna SOLANT Designs for Satellite and Terrestrial Communications", IEEE Trans. Antennas and Propagation, vol-51, no-8, page- 2028- 2034, 2003.

[3] S.V Shynu, M. J. Roo Ons, M.J Ammann, S. McCormack and B. Norton, "Inset fed Microstrip Patch Antenna with Integrated Polycrystalline Photovoltaic Solar Cell", European Conference on Antennas and Propagation, EUCAP-2007, Edinburgh, 2007. 
[4] C.A Balanis, “Antenna Theory- Analysis and Design”, $2^{\text {nd }}$ ed. John Wiley and Sons.

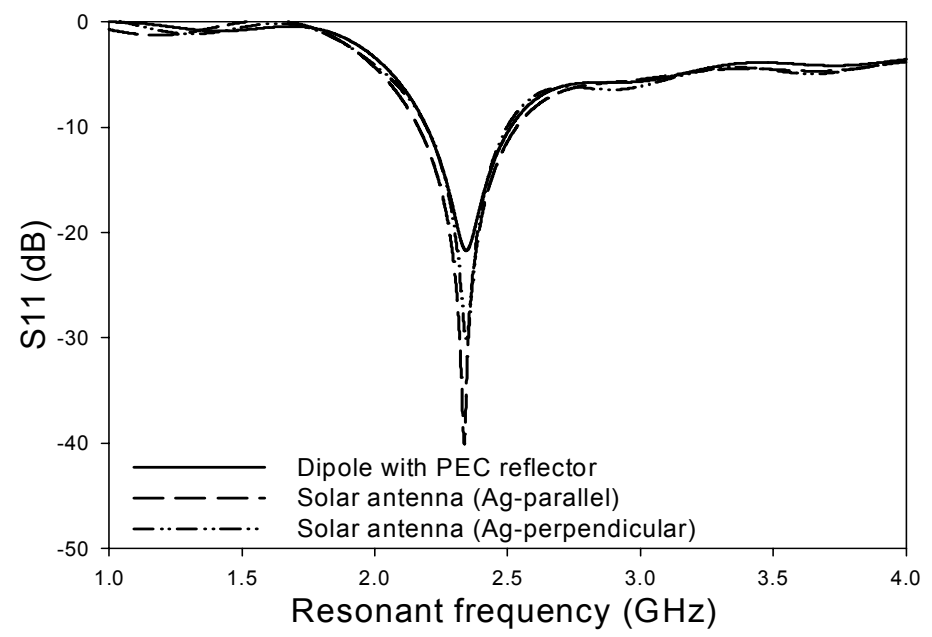

Figure 2. Simulated $\mathrm{S}_{11}$ of the two different Ag-bus bar orientations of solar antenna compared to an ideal shorted patch with PEC

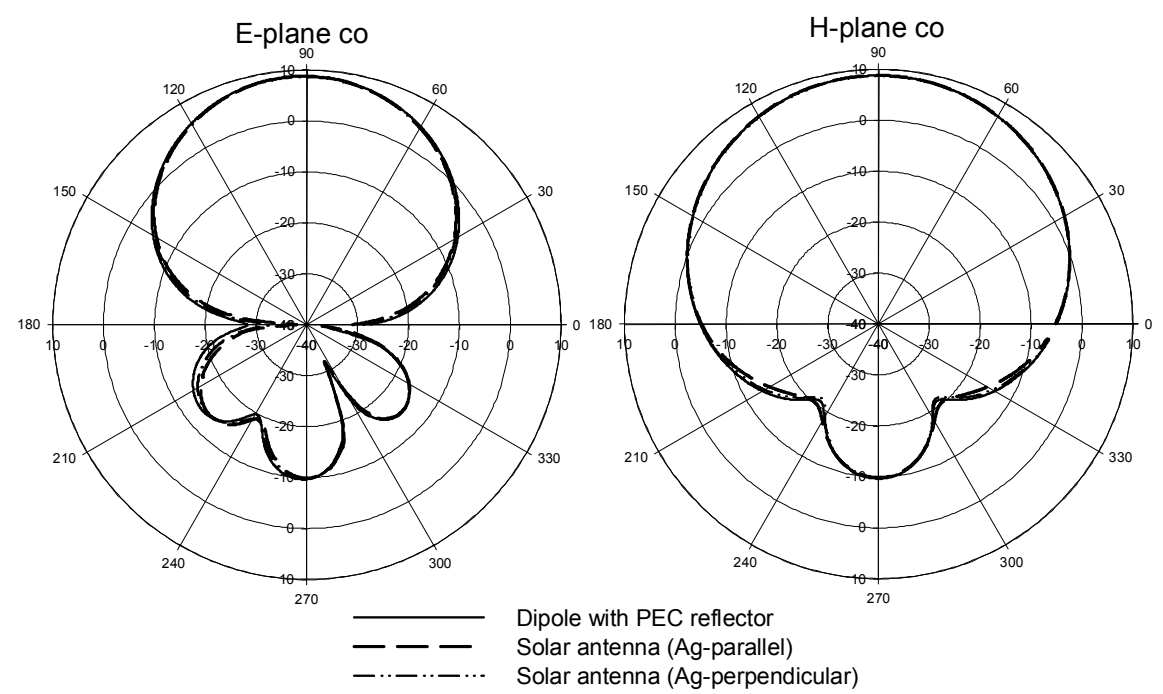

Figure 3. E-plane (x-y) and H-plane (x-z) co-polar radiation patterns for the proposed solar antenna

Table I. Summary of simulated results

\begin{tabular}{cccc}
\hline Antenna type & $\begin{array}{c}\text { Res. freq. } \\
(\mathrm{GHz})\end{array}$ & $\begin{array}{c}\% \\
\text { Bandwidth }\end{array}$ & Gain (dBi) \\
\hline Solar antenna (Ag-parallel) & 2.3390 & 15.8 & 8.60 \\
Solar antenna (Ag-perpendicular) & 2.3484 & 13.1 & 8.60 \\
Dipole with PEC reflector & 2.3474 & 13.4 & 8.84 \\
\hline
\end{tabular}

